\title{
Comparative Study of Paraoxonase and Cholinestrase Enzymes Activities in Diagnosis of Organophosphorus Insecticide Intoxication
}

\author{
Mona Elgohary', Nahla El Ashmawy², Rabab El Kelany', Arwa Abo Elfadl'1, \\ Ghada El-Sarnagawy ${ }^{1}$
}

\author{
${ }^{1}$ Forensic Medicine and Clinical Toxicology Department, Faculty of Medicine \\ ${ }^{2}$ Biochemistry Department, Faculty of Pharmacy \\ Tanta University, Tanta, Egypt.
}

\begin{abstract}
Many efforts have been made to evaluate organophosphorus (OP) toxicity by sensitive biomarkers. Therefore, the aim of this work is to evaluate cholinesterase and paraoxonase (PON1) enzymes activities as diagnostic tools in acute $\&$ chronic organophosphorus toxicity with poisoning severity assessment. The present study was conducted on 90 adult men after taking their informed consent, they were divided into three groups; group (I) included thirty patients who were acutely exposed to organophosphorus insecticides (OPI). Group (II) included thirty farm workers chronically exposed to OP. Group (III) included thirty healthy matched volunteers served as control group. The severity of symptoms and signs of acute OP poisoning was graded into mild, moderate and severe grade. Long term pesticide exposure intensity was estimated depending on mixing, application methods, repair activities and use of personal protective equipment (PPE). Exposure intensity score $=$ (Mix + Apply + Repair) $x$ PPE. Butyrylcholinesterase (BuChE), acetylcholinesterase (AChE) and paraoxonase (PON1) enzymes activities were determined. The result of the current study revealed significant decrease in BuChE, $\mathrm{AChE}$ and PON1 in groups I and II when compared to group III. Moreover, BuChE and AChE enzymes were significantly decreased in group I when compared to group II. Significant positive correlation was detected between AChE enzyme activity and both BuChE and PON1 enzymes activities in group I. However, group II showed significant positive correlations between BuChE enzyme activity and the activity of each of AChE and PON1. Moreover, there was significant decrease in AChE enzyme activity in severe cases compared to mild and moderate cases in group I. Nevertheless, group II registered significant decrease in BuChE, $\mathrm{AChE}$ and $\mathrm{PON}-1$ when Pesticide Exposure Intensity Score is more than 10.
\end{abstract}

\section{Introduction}

$\mathrm{O}$ rganophosphorus compounds (OPCs) are extensively used in agricultural and household environments to control insects and pests. Because of their wide spread use and easy accessibility, OP toxicity is an important global health problem especially in developing countries (Buyukokurog et al., 2008). In Egypt, organophosphorus intoxication is a common cause of morbidity and mortality. It represents more than $50 \%$ of insecticide poisoned patients (Ibrahim et al., 2011).

Organophosphorus compounds act as powerful acetylcholinesterase enzyme (AChE) inhibitors, resulting in acetylcholine accumulation and overstimulation of cholinergic synapses, neuromuscular junction and central nervous system.
The cholinergic overload leads to characteristic muscarinic, nicotinic and central nervous system symptoms and signs (Exner and Ayalar, 2009).

Diagnosis is based on clinical suspicion, the characteristic clinical signs, smell of pesticides or solvents and reduced butyrylcholinesterase or acetylcholinesterase activities in the blood (Eddleston et al., 2008). Therefore, blood cholinesterase enzymes activities have become relatively simple assessing procedure for OP human exposure extent. Such assays are considered as diagnostic tool rather than prognostic one (Kamanyire and Karalliedde, 2004).

Butyrylcholinesterase enzyme is more sensitive than AChE as the plasma cholinesterase enzyme is the first binding site of OPCs following their 
absorption (Makhaeva et al., 2009). However, acetylcholinesterase is more specific than $\mathrm{BuChE}$, as, it is inhibited in a parallel manner to neuronal $\mathrm{AChE}$ (Jintana et al., 2009).

Individual susceptibility and exposure level have been reported to play a critical role in OP exposure outcome. Individual susceptibility is controlled by several polymorphic key enzymes such as plasma paraoxonase (PON1) enzyme (Hernandez et al., 2005).

Paraoxonase (PON1) is a high density lipoprotein-associated enzyme which is capable to hydrolyze multiple substrates including aromatic carboxylic acids, nerve gases and several organophosphorus metabolic products. Paraoxonase enzyme displays several polymorphisms that influence both its level and catalytic activity. Therefore, it could be considered as a good indicator to assess organophosphorus detoxification rate, poisoning severity and consequently susceptibility to develop organophosphorus poisoning (Costa et al., 2008).

Since paraoxonase is considered a biomarker of susceptibility to organophosphorus poisoning, and cholinesterase enzymes are accepted as biomarkers of organophosphorus exposure, the goal of the current study is to evaluate cholinesterase and paraoxonase (PON1) enzymes activities as diagnostic tools in acute and chronic OP exposures with poisoning severity assessment.

\section{Patients and methods}

This randomized cross sectional comparative study was performed at Poison Control Unit, Tanta University Emergency Hospital. It was approved by the Research Ethical Committee, Faculty of Medicine, Tanta University.

Patients included in this study were acutely and chronically exposed to organophosphorus insecticides (OPI). Patients with any pre-existing chronic diseases including; hypertension, diabetes, hepatic, renal, cardiovascular diseases and cancer were excluded. Written informed consent was obtained from each patient.

Ninety adult male patients and volunteers have participated in the study. They were grouped into group I, included thirty acutely OP poisoned patients, group II, included thirty farm workers chronically exposed to organophosphorus compounds and group III, included thirty healthy adult volunteers matched for age and socioeconomic level.

Diagnosis of acute organophosphorus poisoning (OPP) was based on history of OP insecticides exposure, characteristic OPP symptoms and signs, clinical improvement after atropine and oximes (toxogonin) administration and decrease in serum or RBCs cholinesterase enzymes activities (Karki et al., 2004). Sociodemographic data (age, occupation, education, residence, marital status and special habits) were registered.
Chlorpyrifos, Profenofos and malathion were the most commonly OP compounds to which the patients were exposed in both acute and chronic OP exposures. The severity of symptoms and signs of acute OPP was graded according to Minton and Murray (1988) into: Mild grade OPP: Fatigue, headache, blurred vision, dizziness, nausea, vomiting, excessive sweating, salivation, abdominal pain and tightness in chest. Moderate grade OPP: Symptoms of mild poisoning plus muscular fasciculation, weakness, inability to walk and miosis. Severe grade OPP: Symptoms of moderate poisoning plus unconsciousness, flaccid paralysis, respiratory distress, cyanosis and marked miosis with loss of pupil reflexes.

Long term pesticide exposure intensity was estimated according to Dosemeci et al. (2002). It is based on four basic variable i.e. mixing, application methods, repair activities and use of personal protective equipment (PPE). Exposure intensity score $=$ (Mix + Apply + Repair) x PPE. After calculation, the pesticides applicators were categorized according to Coble et al. (2005) into $<5$ for low exposure, 5-10 for medium exposure and $>10$ for high exposure.

Venous blood sample $(5 \mathrm{ml})$ was collected from all subjects immediately after admission and before administration of any medication and was divided into 2 portions. The first portions $(3 \mathrm{ml})$ was centrifuged for $10 \mathrm{~min}$ at 2500 r.p.m. Serum was collected and kept at $-20^{\circ} \mathrm{C}$ until assay of paraoxonase and butyrylcholinesterase activities. The second portion of blood $(2 \mathrm{ml})$ was collected in EDTA tube for assay of erythrocyte cholinesterase activity.

Butyrylcholinesterase and acetylcholinesterase enzyme activities were determined by using colorimetric method according to Ellman et al. (1961) by using butyrylthiocholine iodide (Aldrich Chemical Co-Ltd., England) and acetylthiocholine iodide as substrates (Sigma- Aldrich, Chemical Company, USA). Paraoxonase enzyme activity was determined colorimetrically by using paraoxon $(\mathrm{O}, \mathrm{O}-$ diethyl O-p-nitrophenyl phosphate; (Sigma- Aldrich, Chemical Company, USA) according to the method of Furlong et al. (1988). Hemoglobin was determined according to Hall and Malia (1991) by using kits obtained from Biodiagnostic Co. Ltd., Egypt.

Results were tabulated and statistical analysis was performed with Statistical Package for the Social Science (SPSS) version 17 computer program (Landau and Everitt, 2004). Analysis of data was done by Chisquare. Comparison between the studied groups was performed with one way ANOVA (F-testing). Correlation between variables was evaluated using Pearson correlation coefficient. The level of statistical significance was set at $\mathrm{p}$ value below 0.05 .

\section{Results}

Table (1) illustrates sociodemographic data of the three studied groups. There was significant difference in occupational and smoking distribution among the 
studied groups. Farm workers represented $40 \%$ of group I and all members of group II. Concurrently, non smokers represented a peak $(83.33 \%)$ in group I and smokers represented another peak $(70 \%)$ in group II.

Grading of toxicity in acute organophosphorus exposure revealed that 12 patients $(40 \%)$ were evaluated as mild acute OPP, while 10 patients $(33.33 \%)$ were graded as moderate acute OPP and 8 patients $(26.67 \%)$ belonged to the severe grade. The mean of Pesticide Exposure Intensity Score (PEIS) in chronic organophosphorus exposure (group II) was $9.58 \pm 2.79$ (range from 1.2 to 14 ). Seventeen subjects (56.67\%) were highly exposed; they have shown PEIS of more than 10 . While 11 subjects $(36.67 \%)$ registered PEIS from 5-10, and 2 subjects (6.67\%) had PEIS less than 5 .

Analysis of cholinesterase and paraoxonase enzymes activities revealed significant decrease in BuChE, AChE and PON-1 in groups I and II when compared to group III. Moreover, $\mathrm{BuChE}$ and $\mathrm{AChE}$ enzymes were significantly decreased in group I when compared to group II (Table 2).
In group I, significant positive correlation could be detected between AChE enzyme activity and each of BuChE and PON1 enzymes activities (Figures $1 \& 2)$. However, no significant correlation was found between PON-1 and BuChE enzymes activities $(\mathrm{p}=0.098, \mathrm{r}=0.341)$.

Regarding group II, significant positive correlations were noticed between $\mathrm{BuChE}$ enzyme activity and the activity of each of AChE and PON1 enzymes activities (Figures $3 \& 4$ ). On the other hand, no significant correlation was detected between PON-1 and AChE enzymes activities $(\mathrm{p}=0.253, \mathrm{r}=0.215)$.

Table (3) shows significant decrease in AChE enzyme activities in severe cases compared to mild and moderate cases in group I. However, the severity grade didn't significantly affect the $\mathrm{BuCh}$ and PON-1 enzymes activities. Nevertheless, group II registered significant decrease in $\mathrm{BuChE}, \mathrm{AChE}$ and $\mathrm{PON}-1$ when Pesticide Exposure Intensity Score is more than 10 (Table 4).

Table (1): Chi-Square analysis of sociodemoraphic data among the three studied groups.

\begin{tabular}{|c|c|c|c|c|c|c|}
\hline \multirow[b]{2}{*}{ Sociodemoraphic data } & \multicolumn{4}{|c|}{ Groups (No, \%) } & \multicolumn{2}{|c|}{ Chi-Square } \\
\hline & $\begin{array}{c}\text { Group I } \\
n=30\end{array}$ & $\begin{array}{c}\text { Group II } \\
n=30\end{array}$ & $\begin{array}{c}\text { Group III } \\
n=30\end{array}$ & Total & $\mathbf{X}^{2}$ & P-value \\
\hline \multicolumn{5}{|l|}{ (1) Age groups } & \multirow{6}{*}{9.93} & \multirow{6}{*}{0.26} \\
\hline$<20$ & $2(6.67 \%)$ & $0(0 \%)$ & $2(6.67 \%)$ & $4(4.44 \%)$ & & \\
\hline $20-30$ & $11(36.67 \%)$ & $4(13.33 \%)$ & $9(30 \%)$ & $24(26.67 \%)$ & & \\
\hline $30-40$ & $10(33.33 \%)$ & $13(43.33 \%)$ & $9(30 \%)$ & $32(35.56 \%)$ & & \\
\hline $40-50$ & $3(10 \%)$ & $7(23.33 \%)$ & $6(20 \%)$ & $16(17.78 \%)$ & & \\
\hline$>50$ & $4(13.33 \%)$ & $6(20 \%)$ & $4(13.33 \%)$ & $14(15.56 \%)$ & & \\
\hline \multicolumn{5}{|l|}{ (2) Occupation } & \multirow{6}{*}{93.92} & \multirow{6}{*}{$0.001 *$} \\
\hline Manual worker & $5(16.67 \%)$ & $0(0 \%)$ & $20(66.67 \%)$ & $25(27.78 \%)$ & & \\
\hline Unemployed & $10(33.33 \%)$ & $0(0 \%)$ & $8(26.67 \%)$ & $18(20 \%)$ & & \\
\hline Student & $1(3.33 \%)$ & $0(0 \%)$ & $2(6.67 \%)$ & $3(3.33 \%)$ & & \\
\hline Farm worker & $12(40 \%)$ & $30(100 \%)$ & $0(0 \%)$ & $42(46.67 \%)$ & & \\
\hline Employer & $2(6.67 \%)$ & $0(0 \%)$ & $0(0 \%)$ & $2(6.67 \%)$ & & \\
\hline \multicolumn{5}{|l|}{ (3) Residence } & \multirow{3}{*}{4.25} & \multirow{3}{*}{0.11} \\
\hline Rural & $22(73.33 \%)$ & $28(93.33 \%)$ & $24(80 \%)$ & $74(82.22 \%)$ & & \\
\hline Urban & $8(26.67 \%)$ & $2(6.67 \%)$ & $6(20 \%)$ & $16(17.78 \%)$ & & \\
\hline \multicolumn{5}{|l|}{ (4) Education } & \multirow{5}{*}{11.56} & \multirow{5}{*}{0.07} \\
\hline Illiterate & $10(33.33 \%)$ & $12(40 \%)$ & $4(13.33 \%)$ & $26(28.89 \%)$ & & \\
\hline Low & $2(6.67 \%)$ & $2(6.67 \%)$ & $0(0 \%)$ & $4(4.44 \%)$ & & \\
\hline Moderate & $16(53 \%)$ & $13(43.33 \%)$ & $24(80 \%)$ & $53(58.89 \%)$ & & \\
\hline High & $2(6.67 \%)$ & $3(10 \%)$ & $2(6.67 \%)$ & $7(7.78 \%)$ & & \\
\hline \multicolumn{5}{|l|}{ (5) Marital state } & \multirow{3}{*}{3.49} & \multirow{3}{*}{0.17} \\
\hline Married & $15(50 \%)$ & $22(73.33 \%)$ & $19(63.33 \%)$ & $56(62.22 \%)$ & & \\
\hline Single & $15(50 \%)$ & $8(26.67 \%)$ & $11(36.67 \%)$ & $34(37.78 \%)$ & & \\
\hline \multicolumn{5}{|l|}{ (6) Special habits } & \multirow{3}{*}{18.61} & \multirow{3}{*}{$<0.001 *$} \\
\hline Smokers & $5(16.67 \%)$ & $21(70 \%)$ & $10(33.33 \%)$ & $36(40 \%)$ & & \\
\hline Non- smokers & $25(83.33 \%)$ & $9(30 \%)$ & $20(66.67 \%)$ & $54(60 \%)$ & & \\
\hline Total & $30(100 \%)$ & $30(100 \%)$ & $30(100 \%)$ & $90(100 \%)$ & & \\
\hline
\end{tabular}


Table (2): ANOVA and TUKEY'S test analysis of enzymes activities in the three studied groups.

\begin{tabular}{|c|c|c|c|c|c|c|c|c|}
\hline & $\begin{array}{c}\text { Group I } \\
\mathrm{n}=30\end{array}$ & $\begin{array}{c}\text { Group II } \\
\mathrm{n}=30\end{array}$ & $\begin{array}{c}\text { Group III } \\
\mathrm{n}=30\end{array}$ & \multicolumn{2}{|c|}{ ANOVA } & \multicolumn{3}{|c|}{ TUKEY'S test } \\
\hline \multicolumn{4}{|c|}{ Butyrylcholinesterase (U/L) } & $\mathbf{F}$ & P-value & $\begin{array}{l}\text { Group } \\
\text { I \& III }\end{array}$ & $\begin{array}{l}\text { Group } \\
\text { II \& III }\end{array}$ & $\begin{array}{l}\text { Group } \\
\text { I \& II }\end{array}$ \\
\hline Range & $830.88-6250$ & $1470-5588.23$ & $\begin{array}{l}2941.17- \\
5220.58\end{array}$ & \multirow[t]{2}{*}{17.7} & \multirow[t]{2}{*}{$<0.001 *$} & \multirow[t]{2}{*}{$<0.001 *$} & \multirow[t]{2}{*}{$0.04 *$} & \multirow[t]{2}{*}{$0.001 *$} \\
\hline Mean \pm SD & $2302.26 \pm 1191.48$ & $3265.09 \pm 1164.68$ & $3868.34 \pm 616.01$ & & & & & \\
\hline \multicolumn{4}{|c|}{ Acetylcholinesterase $(\mathrm{U} / \mathrm{gHb})$} & \multirow{3}{*}{32.4} & \multirow{3}{*}{$<0.001 *$} & \multirow{3}{*}{$<0.001^{*}$} & \multirow{3}{*}{$<0.001 *$} & \multirow{3}{*}{$0.004 *$} \\
\hline Range & $4.54-20.70$ & $5.51-28.64$ & $14.32-28.01$ & & & & & \\
\hline Mean \pm SD & $12.06 \pm 4.38$ & $16.43 \pm 6.56$ & $22.55 \pm 3.83$ & & & & & \\
\hline \multicolumn{4}{|c|}{ Paraononase $(\mathrm{U} / \mathrm{ml})$} & \multirow{3}{*}{13.3} & \multirow{3}{*}{$0.001 *$} & \multirow{3}{*}{$<0.001 *$} & \multirow{3}{*}{$0.01 *$} & \multirow{3}{*}{0.08} \\
\hline Range & $5.88-90.97$ & $16.05-132.18$ & $42.81-148.23$ & & & & & \\
\hline Mean \pm SD & $49.56 \pm 24.36$ & $65.94 \pm 30.36$ & $88.35 \pm 32.17$ & & & & & \\
\hline
\end{tabular}

*Significant at $p$-value $<0.05 ; n=30$ for each group

Table (3): ANOVA test analysis of enzymes activities and grades of severity in group I.

\begin{tabular}{|l|c|c|c|c|c|}
\hline \multirow{2}{*}{ Group I enzyme activities } & Mild (n=12) & Moderate(n=10) & Severe(n=8) & \multicolumn{2}{c|}{ ANOVA } \\
\cline { 2 - 6 } & Mean \pm SD & Mean \pm SD & Mean \pm SD & F & P-value \\
\hline $\mathrm{BuChE}(\mathrm{U} / \mathrm{L})$ & $2867.17 \pm 1300.48$ & $1566.91 \pm 674.27$ & $2374.08 \pm 1146.15$ & 3.02 & 0.06 \\
\hline $\mathrm{AChE}(\mathrm{U} / \mathrm{gHb})$ & $14.33 \pm 2.92$ & $11.18 \pm 4.94$ & $9.74 \pm 4.31$ & 3.40 & $0.04 *$ \\
\hline $\mathrm{PON} 1(\mathrm{U} / \mathrm{ml})$ & $59.43 \pm 20.57$ & $46.34 \pm 24.30$ & $38.79 \pm 26.85$ & 1.97 & 0.15 \\
\hline
\end{tabular}

*Significant at p-value $<0.05$

Table (4): ANOVA test analysis of enzymes activity and Pesticides Exposure Intensity Score in group II

\begin{tabular}{|c|c|c|c|c|c|}
\hline \multirow{3}{*}{ Group II enzymes activities } & \multicolumn{3}{|c|}{ Pesticides Exposure Intensity Score } & \multirow{2}{*}{\multicolumn{2}{|c|}{ ANOVA }} \\
\hline & $<\mathbf{5}$ & $5-10$ & $>10$ & & \\
\hline & Mean \pm SD & Mean \pm SD & Mean \pm SD & $\mathbf{F}$ & P-value \\
\hline $\mathrm{BuChE}(\mathrm{U} / \mathrm{L})$ & $3724.26 \pm 67.59$ & $3529.41 \pm 1329.23$ & $3040.05 \pm 1107.19$ & 2.78 & $0.048 *$ \\
\hline $\mathrm{AChE}(\mathrm{U} / \mathrm{gHb})$ & $20.66 \pm 6.87$ & $14.33 \pm 5.28$ & $11.02 \pm 1.41$ & 4.84 & $0.01 *$ \\
\hline PON1(U/ml) & $123.88 \pm 11.73$ & $62.89 \pm 22.42$ & $60.13 \pm 33.62$ & 5.01 & $0.01 *$ \\
\hline
\end{tabular}

*Significant at p-value $<0.05$

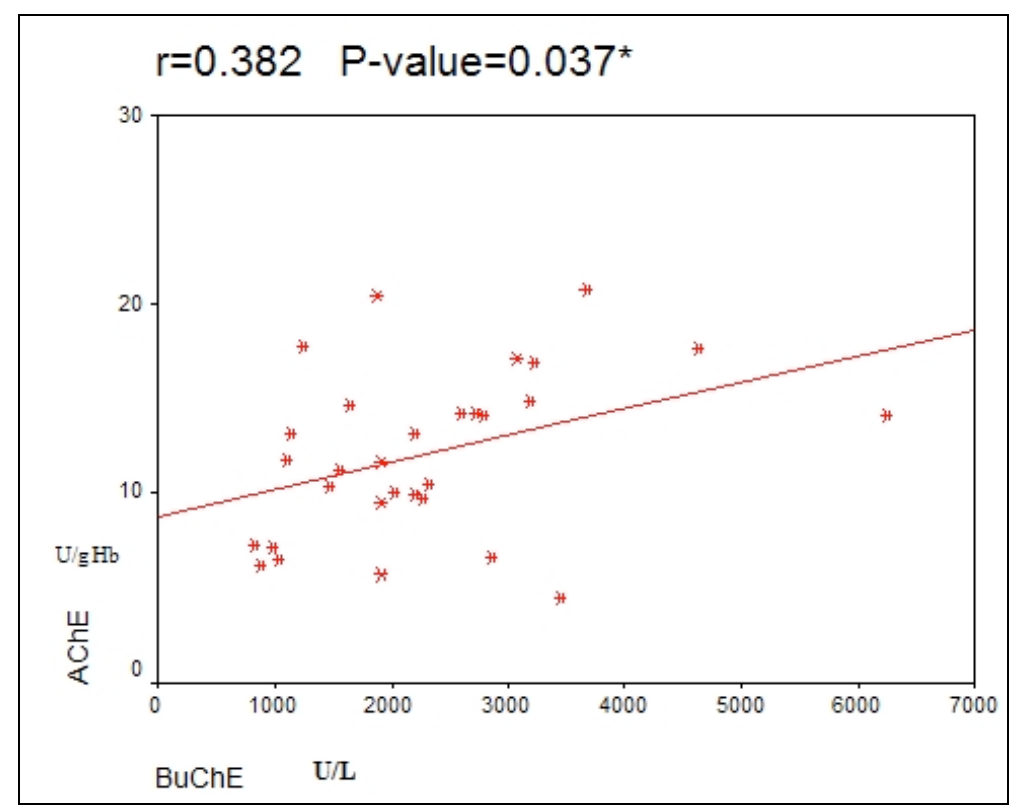

Fig (1): Pearson correlation between $\mathrm{AChE}$ and BuChE enzymes activities in group I patients 


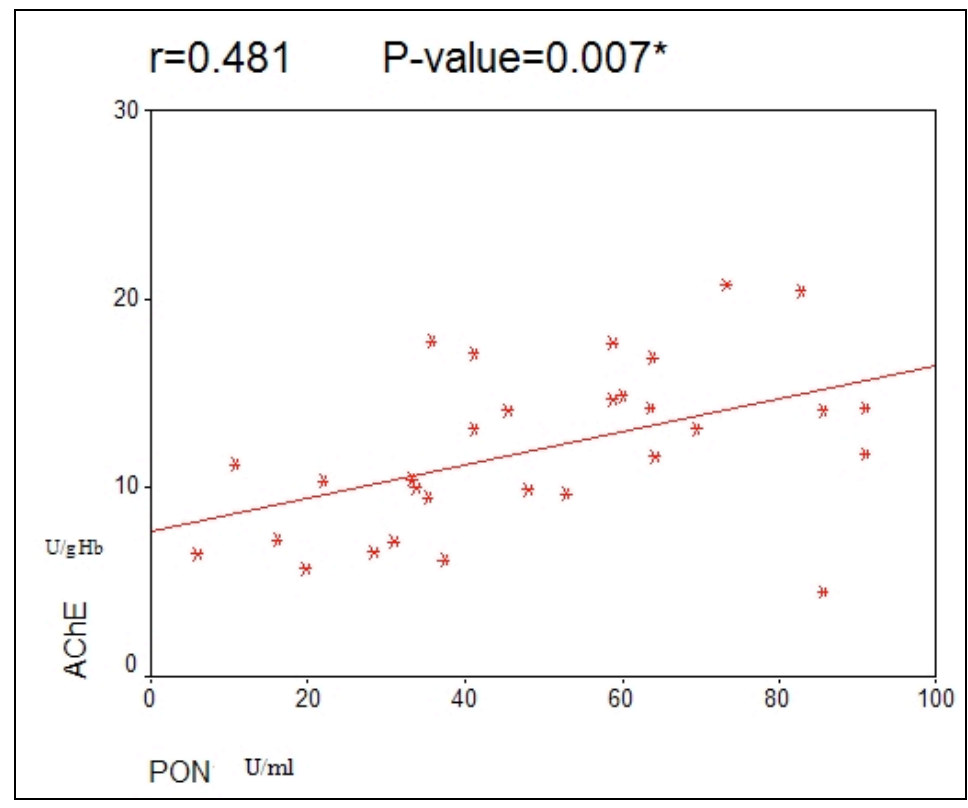

Fig (2): Pearson correlation between AChE and PON1 enzymes activities in group I patients.

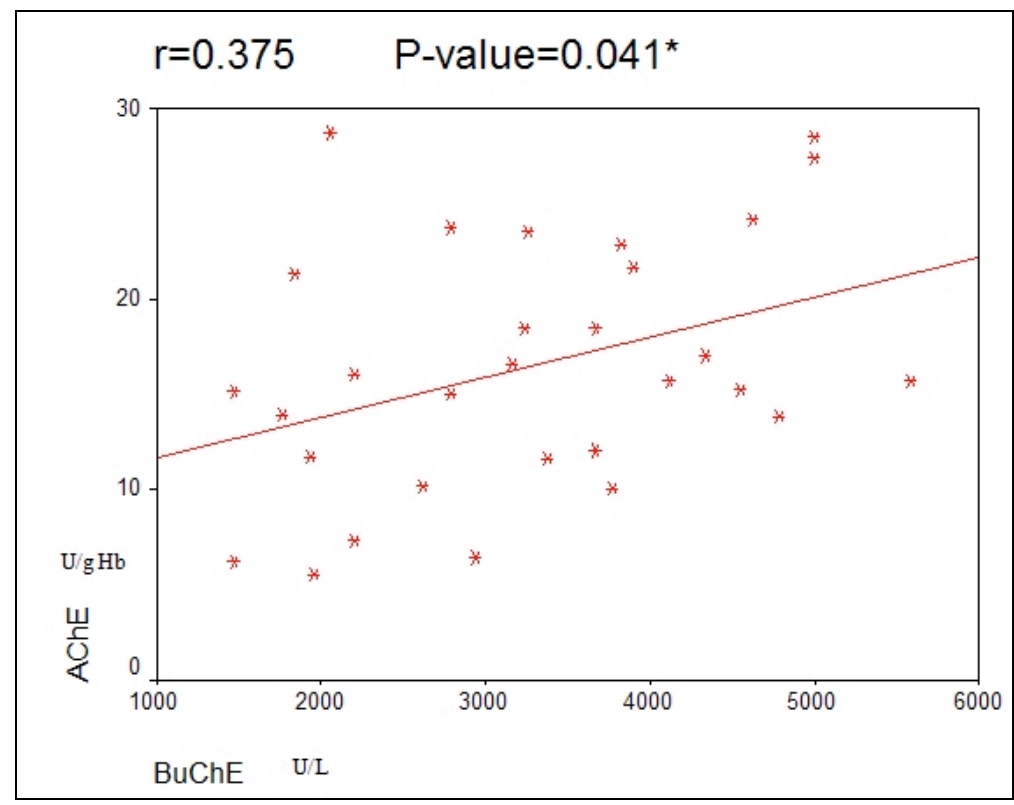

Fig (3): Pearson correlation between BuChE and AChE enzymes activities in group II farm workers. 


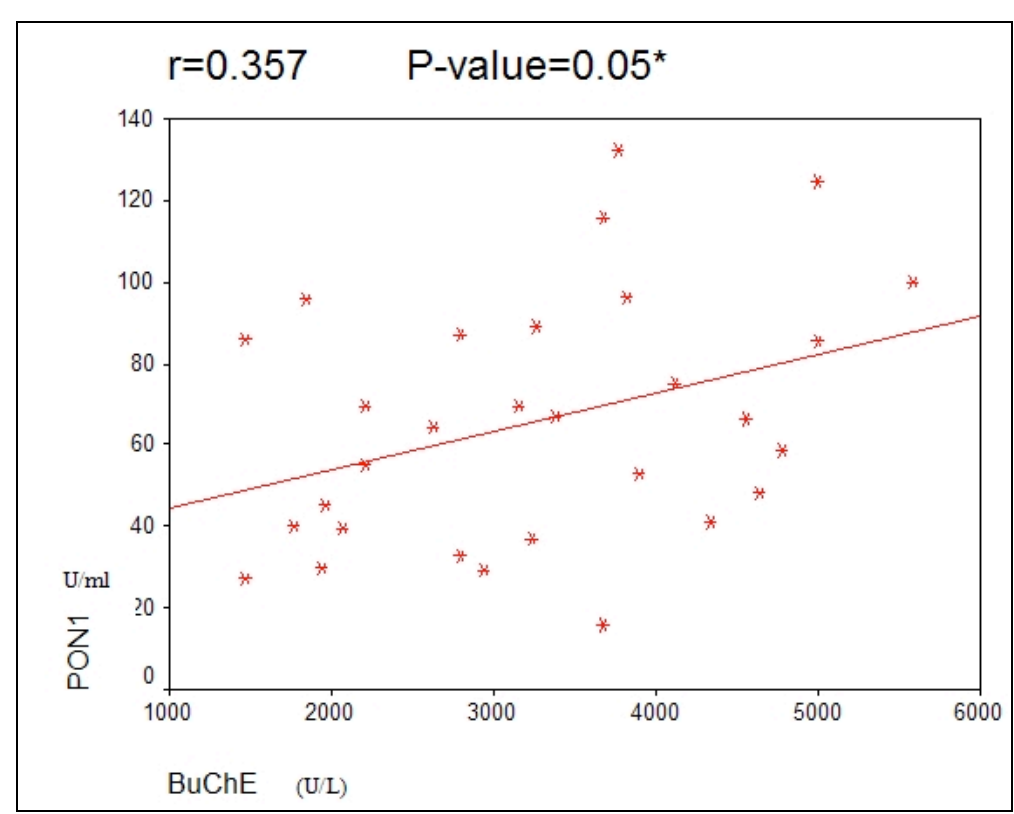

Fig (4): Pearson correlation between BuChE and PON-1 enzymes activities in group II farm workers.

\section{Discussion}

This randomized cross sectional comparative study was performed to evaluate cholinesterase and paraoxonase (PON1) enzymes activities as diagnostic tools in acute and chronic OP exposures with poisoning severity assessment.

Results obtained in this study from group I patients revealed that the mean age was $31.76 \pm 11.93$ years and $36.67 \%$ were between $20-30$ years. In addition, $40 \%$ of acute OP poisoned patients were farm workers which could be attributed to the wide spread OPCs accessibility during working in agriculture with misuse of protective devices (Magauzi et al., 2011; Mishra et al., 2012). These results coincide with the results recorded by Gannur et al. (2008) and Shah Harsh et al. (2012) who reported that the majority of acute OP poisoned patients were between 21-30 years and the greater part of patients were agriculture workers.

Accordingly, $73.33 \%$ of patients in group I were recorded from rural areas. So, it could be explained by widespread use of OPCs in the rural agricultural society in the Delta region together with its low cost. These findings were in the same line with other studies (Gannur et al. 2008; Patel and Tekade 2011).

The low level of education in farm workers constitutes a risk factor for OPP being unable to read and follow the safety instructions for pesticides use. A fact that comes in line with the results of the current study, where $53.33 \%$ of group I patients were moderately educated and $33.33 \%$ were completely illiterate. Similar finding were recorded by Nigam et al. (2004) in Bhopal region.

Results obtained in this study from group II Egyptian farm workers revealed that, the mean age was
$40.03 \pm 9.06$ years and $43.33 \%$ of subjects were between (30-40 years). Likewise, a study in Thailand by Jintana et al. (2009) reported that the mean age of exposed farm workers was $39.9 \pm 1.13$ years and $32.22 \%$ of cases were between (36-45 years). In the present study, $43.33 \%$ of farm workers were moderately educated. This finding shows consistency with those obtained by Hofmann et al. (2010) and Imran and Dilshad (2011).

The current study reported significant decrease in $\mathrm{BuChE}$ and $\mathrm{AChE}$ activities in groups I and II when compared to control group. Previously, BuChE and AChE activities were recorded to be significantly decreased in both acute and chronic OP exposures (Brahmi et al., 2006; Sozmen et al., 2007; Chakraborty et al., 2009; Prabodh et al., 2012).

In the present study, BuChE and AChE were significantly decreased in group I when compared to group II. This finding can be explained on the basis that in acute OP exposure, there is marked phosphorylation of $\mathrm{ChE}$ under the influence of the high dose of OP exposure in a very short time. On the other hand in chronic OPP, there is exposure to low dose of OP over a long time (Jokanovic and Stojiljkovic, 2006; Balali-Mood and Balali-Mood, 2008). Chronic OP exposure is irregular that may give enough time for ChE recovery. However, such recovery may be incomplete particularly in Egyptian farmers as they are regular sprayers in the three agricultural seasons.

Controversial results were reported by Smit et al. (2003), who demonstrated that AChE activity registered significant decrease during high exposure period and significant increase during low exposure period in Sri Lankan farmers. They interpreted these findings by the different exposure degrees as Sri 
Lankan farmers are irregularly sprayers, therefore, there was enough time for cholinesterase enzyme adaptation or compensation during low exposure period that increase the cholinesterase production with subsequent central muscarinic and nicotinic receptors down regulation (Ciesielski et al., 1994). However, such compensation doesn't occur in Egyptian farmers because they are regular sprayers in every agricultural season. So, there is no enough time for enzyme adaptation to occur. In other words, the nonstop exposure of Egyptian farmers to OPCs is considered to be responsible for continuous inhibition of cholinesterase enzymes.

Moreover, the present study demonstrated significant positive correlation between $\mathrm{BuChE}$ and AChE activities in groups I and II. This finding is in agreement with other studies carried out by Akgur et al. (2003) and Joshaghani et al. (2007). However, Thetkathuek et al. (2005) demonstrated significant decrease in BuChE without alteration in AChE activity in chlorpyrifos applicators. Eaton et al. (2008) stated that, plasma BuChE is substantially more sensitive to inhibition by chlorpyrifos than erythrocyte AChE. In the present study, farm workers used a mixture of different OPCs which may together display different degrees of cholinesterase enzymes inhibition.

The present study showed an inhibition in PON1 in group I (about 44\%) as compared to control group. This finding was consistent with Sozmen et al. (2002) who observed that $30 \%$ of PON1 activity was lower in acutely OP exposed patients than control. Conversely, Tanrisev and Toprak (2004) didn't report any significant difference in PON1 activity in acutely OP poisoned patients.

Moreover, the current study observed significant decrease in PON1 in subjects of group II (about 30\%) when compared to control group. This finding shows consistency with other studies carried out by Hoffmann et al. (2009) and Singh et al. (2011). However, Sirivarasai et al. (2007) and Zhou et al. (2007) didn't notice any significant change in PON1 activity between OP chronically exposed subjects and control.

The OP induced decrease in PON1 activity may be due to direct inhibition without affecting enzyme synthesis or clearance. The mechanism by which OPCs may inactivate PON1 is still in debate. However, it may be due to a competitive effect of the intoxicating OP during the in vitro assay (Sozmen et al., 2002), or due to the metabolic activation of OPCs to highly reactive intermediates which might account for the decreased PON1 activity by oxidative stress challenge (Hernandez et al., 2008). Furthermore, PON1 activity may not be affected significantly in OP exposed patients who don't have any special genetic susceptibility to OPP (Tanrisev and Toprak, 2004). It is well known that the distribution of the polymorphic alleles of PON1 is a major factor for determining enzyme activity and assessing individuals' susceptibility to OPCs (Costa et al., 2012). The latter theory makes a sense and provides an explanation to the difference in severity of OPP among patients having similar degree of OP exposure.

On the other hand, Hernandez et al. (2004) and Browne et al. (2006) demonstrated higher PON1 level in chronic OP exposed farm workers at post exposure period, which can be attributed to adaptive PON1 response following chronic OP exposure.

The existing study observed significant positive correlation between AChE and PON1 enzymes activity in patients of group I. This finding shows consistency with study in India carried out by Goel et al. (2012). Additionally, studies in transgenic mice have demonstrated that low PON1 activity is associated with greater brain AChE inhibition after chlorpyrifos and diazinon oxon exposures (Li et al., 2000; Cole et al., 2003).

Goel et al. (2012) provided an explanation for the positive correlation between PON1 and AChE on the basis that PON1 can hydrolyze several OPCs oxon derivatives (active form of OPCs), thereby, preventing ChE from inhibition by OPCs. At the same time, paraoxonase enzyme may protect the RBCs membrane from lipid peroxidation through its antioxidant properties (Eskenazi et al., 2010). So, it may decreases or limits the degree of AChE inhibition.

Conversely, Akgur et al. (2003) demonstrated lack of correlation between PON1 enzyme and both cholinesterase enzymes activities in acute OP poisoned patients. It could be attributed to high acute organophosphate exposure that gave little opportunity for paraoxonases to afford much protection than lowlevel chronic exposure, where additional time for enzymatic detoxification is available.

Moreover, the current study recorded significant positive correlation between PON1 and BuChE activities in group II farm workers. A result which is in accordance with the study carried out by Sozmen et al. (2007), Chia et al. (2009) and Hoffmann et al. (2009) who declared that, BuChE and PON1 activities decreased in parallel manner in farmers after chronic OP exposure when compared to either control or to their baseline levels.

However in the current study, no significant correlation could be observed between PON1 and AChE enzymes activities in group II. While, Singh et al. (2011) found significant positive correlation between AChE and PON1 level in chronic OP exposed farm workers. Hernandez et al. (2005) and Sirivarasai et al. (2007) demonstrated decrease in cholinesterase enzymes without PON1 reduction in chronic OP exposure. Such variation is attributed to PON1 
polymorphism among individuals that will affect its level and consequently its catalytic effect on metabolism of active OPCs intermediate with difference in individual susceptibility to OPP.

Significant decreases in enzymes activities were found in subjects of group II who's Pesticide Exposure Intensity Score were more than 10. This finding is parallel with Hofmann et al. (2010) and Sozmen et al. (2007) who observed BuChE inhibition with increasing OPCs exposure score.

\section{Conclusion}

The three enzymes AChE, BuChE and PON1were inhibited in both acute and chronic organophosphorus exposure. The degree of inhibition in chronic OP exposure was correlated with the increased pesticides exposure intensity score. On the other hand, AChE activity is much more affected by the severity of acute poisoning.

\section{Recommendations}

In the light of the present study, the following recommendations are proposed:

1- Measurement of paraoxonase enzyme activity is recommended to confirm both acute and chronic organophosphorus exposures particularly when measurement of cholinesterase enzymes activity levels are not available.

2- To assess the severity of acute organophosphorus poisoning, acetylcholinesterase enzyme activity level should be measured at hospital admission (The most expensive, most specific and needs more experience).

3- Indirect exposure assessment by using Pesticides Exposure Intensity Score is recommended as it can provide information of the potential hazard to human health especially when measurement of biological markers is not available.

4- Farm workers should be provided with continuous health education programs concerning; hazards of agricultural practices, encouraging them for safe and careful pesticides use, for example; mixing the OP pesticides should be carefully done by a stick or paddle, applying pesticides and repairing equipments should be done properly with adequate personal protective equipments. After spraying OP pesticides, farm workers should take shower and change their clothes. Education of Pesticides Exposure Intensity Score as a self assessment indicator for pesticides exposure.
5- Restricting availability and uncontrolled sale of organophosphorus compounds, banning more toxic ones and using safer pesticides are recommended to reduce the incidence of organophosphorus poisoning.

6- It is recommended to have pre-employment base line and periodic measurement of cholinesterase and paraoxonase enzymes activity levels for farm workers to determine the extent of chronic OPP after exposure.

7- Farm workers should avoid their nonstop exposure to pesticides throughout the year by taking periods of non exposure to offer enough time for their enzymes to recover and return to their normal levels.

8- Further studies are recommended to find the relation between the mode of treatment and enzyme activities.

\section{References}

Akgur SA, Ozturk P, Solak I et al., (2003): Human serum paraoxonase (PON1) activity in acute organophosphorous insecticide poisoning. Forensic Sci Int;133 (1-2): 136-140.

Balali-Mood M and Balali-Mood K (2008): Neurotoxic disorders of organophosphorus compounds and their managements. Arch Iranian Med; 11(1): $65-89$.

Brahmi N, Mokline A, Kouraichi N et al., (2006): Prognostic value of human erythrocyte acetyl cholinesterase in acute organophosphate poisoning. Am J of Emerg Med; 24(7): 822827.

Browne RO, Moyal-Segal LB, Zumsteg D et al., (2006): Coding region paraoxonase polymorphisms dictate accentuated neuronal reactions in chronic, sub-threshold pesticide exposure. FASEB J; 20(10): 1733-1735.

Buyukokurog ME, Cemek M, Tosun M et al., (2008): Dantrolene may prevent organophosphateinduced oxidative stress and muscle injury. Pestic Biochem Physiol; 92: 156-163.

Chakraborty S, Mukherjee S, Roychoudhury S et al., (2009): Chronic exposures to cholinesteraseinhibiting pesticides adversely affect respiratory health of agricultural workers in India. J Occup Health; 51(6): 488-497.

Chia SE, Ali S M, Yap PH et al., (2009): Distribution of PON1 polymorphisms PON1Q192R and PON1L55M among Chinese, Malay and Indian males in Singapore and possible susceptibility to organophosphate exposure. Neurotoxicology ; 30(2): 214-219.

Ciesielski S, Loomis DP, Mims SR et al., (1994): Pesticide exposures, cholinesterase depression, and symptoms among North 
Carolina migrant farm workers. Am J Public Health; 84(3): 446-451.

Coble J, Arbuckle T, Lee W et al., (2005): The validation of a pesticide exposure algorithm using biological monitoring results. J Occup Environ Hyg; 2(3): 194-201.

Cole TB, Jampsa RL, Walter BJ et al., (2003): Expression of human paraoxonase (PON1) during development. Pharmacogenetics; 13(6): 357-364.

Costa LG, Cole TB, Jansen KL et al., (2008): Paraoxonase (PON1) and organophosphate toxicity. In: Mackness B (Ed.), The Paraoxonases: Their Role in Disease Development and Xenobiotic Metabolism, pp: 209-220.

Costa LG, Giordano G, Cole TB et al., (2012): Paraoxonase 1 (PON1) as a genetic determinant of susceptibility to organophosphate toxicity. Toxicol, Article in press.

Dosemeci M, Alavanja MC, Rowland AS et al., (2002):. A quantitative approach for estimating exposure to pesticides in the Agricultural Health Study. Ann Occup Hyg; 46: 245-260.

Eaton DL, Daroff RB, Autrup H et al., (2008): Review of the toxicology of chlorpyrifos with an emphasis on human exposure and neurodevelopment. Crit Rev Toxicol; 38(2): $1-125$.

Eddleston M, Buckley N A, Eyer P et al., (2008): Management of acute organophosphorus pesticide poisoning. Lancet; 371(9612): 597607.

Ellman, G L, Courtney K D, Andres V Jr et al., (1961): A new and rapid colorimetric determination of acetylcholinesterase activity. Biochem Pharmacol; 7: 88-95.

Eskenazi B, Huen K, Marks A et al., (2010): PON1 and neurodevelopment in children from the CHAMACOS study exposed to organophosphate pesticides in utero. Environ Health Perspect;118(12): 1775-1781.

Exner CJ and Ayalar GU (2009): Organophosphate and carbamate intoxication in La Paz, Bolivia. J Emerg Med; 36(4): 348-352.

Furlong E, Richter RJ, Seidel SL et al., (1988): Role of genetic polymorphism of human plasma paraoxonase/arylesterase in hydrolysis of the insecticide metabolites chlorpyriphos oxon and paraoxon. Am J Human Genet; 43: 230238.

Gannur DG, Maka P and Reddy KS N (2008): Organophosphorus compound poisoning in
Gulbarga region - A five year study. IJFMT; 2(1): 3-11.

Goel P, Goel K, Singh S et al., (2012): Role of paraoxonases in detoxification of organophosphates. JARBS; 4(4): 320-325.

Hall R and Malia RG (1991): Basic hematologic practice. In: Hall R (Ed), Medical Laboratory Haematology. 2nd edition. Butter worthHeinemann Hally Cowt, Jordan Hill, Oxphord, London, Tokyo, Toront, Sydney, 109.

Hernandez A, Gomez MA, Pena G et al., (2004): Effect of long-term exposure to pesticides on plasma esterases from plastic greenhouse workers. J Toxicol Environ Health A; 67(14): 1095-1108.

Hernandez AF, Lopez O, Pena G et al., (2008): Implications of paraoxonase-1 (PON1) activity and polymorphisms on biochemical and clinical outcomes in workers exposed to pesticides. In: Mackness B et al. (Eds), The Paraoxonases: Their Role in Disease Development and Xenobiotic Metabolism, Protein and Cell Regulation, vol 6, Springer, pp: 221-237.

Hernandez AF, Lopez O, Rodrigo L, et al., (2005): Changes in erythrocyte enzymes in humans long-term exposed to pesticides: influence of several markers of individual susceptibility. Toxicol Lett; 159(1): 13-21.

Hoffmann JN, Keifer MC, Furlong CE et al., (2009): Serum cholinesterase inhibition in relation to paraoxonase-1 (PON1) status among organophosphate-exposed agricultural pesticide handlers. Environ Health Perspect; 117(9): 1402-1408.

Hofmann J N, Keifer M C, De Roos A J et al., (2010): Occupational determinants of serum cholinesterase inhibition among organophosphate-exposed agricultural pesticide handlers in Washington State. Occup Environ Med; 67(6): 375-386.

Ibrahim MA, Masry MK, Moustafa AA et al., (2011): Comparison of the accuracy of two scoring systems in predicting the outcome of organophosphate intoxicated patients admitted to intensive care unit (ICU). EJFS; 1: 41-47.

Imran $H$ and Dilshad KA (2011): Adverse health effects of pesticides exposure in agricultural and industrial workers of developing country. In: Stoytcheva M (Ed) , Pesticides: The Impacts of Pesticides Exposure, pp: 155-178.

Jintana S, Sming K, Krongtong Y et al., (2009): Cholinesterase activity, pesticide exposure and health impact in a population exposed to 
organophosphates. Int Arch Occup Environ Health; 82(7): 833-842.

Jokanovic M and Stojiljkovic MP (2006): Current understanding of the application of pyridinium oximes as cholinesterase reactivators in treatment of organophosphate poisoning. Eur J Pharmacol; 553 (1-3): 10-17.

Joshaghani HR, Ahmadi AR and Mansourian AR (2007): Effects of occupational exposure in pesticide plant on workers' serum and erythrocyte cholinesterase activity. Int $\mathrm{J}$ Occup Med Environ Health; 20 (4): 381-385.

Kamanyire R and Karalliedde L (2004): Organophosphate toxicity and occupational exposure. Occup Med; 54: 69-75.

Karki JA, Ansari S, Bhandary S et al., (2004): Cardiac and electrocardiographic manifestations of acute organophosphate poisoning. Singapore Med J; 45(8): 385-389.

Landau S and Everitt BS (2004): A Handbook of Statistical Analyses Using SPSS. Boca Raton: Chapman \& Hall/CRC Press LLC.

Li WF, Costa LG, Richter RJ et al., (2000): Catalytic efficiency determines the in-vivo efficacy of PON1 for detoxifying organophosphorus compounds. Pharmacogenetics; 10(9): 767779 .

Magauzi R, Mabaera B, Rusakaniko S et al., (2011): Health effects of agrochemicals among farm workers in commercial farms of Kwekwe district, Zimbabwe. Pan Afr Med J; 9: 26.

Makhaeva G, Rudakova E, Boltneva N et al., (2009): Blood Esterases as a Complex Biomarker for Exposure to Organophosphorus. In: Dishovsky $\mathrm{C}$ and Pivovarovi A (Eds): Counteraction to Chemical and Biological Terrorism in East European Countries NATO Science for Peace and Security Series A: Chemistry and Biology. Springer Netherlands, 177-194.

Minton NA and Murray VS (1988): A review of organophosphate poisoning. Med Toxicol Adverse Drug Exp; 3(5): 350-375.

Mishra A, Shukla SK, Yadav MK et al., (2012): Epidemiological Study of Medicolegal Organophosphorus Poisoning in Central Region of Nepal. J Forensic Res: 3(9): 1-5.

Nigam M, Jain AK, Dubey BP et al., (2004): Trends of organophosphorus poisoning in Bhopal region an autopsy based study; JIAFM; 26(2): 62-65.

Patel DJ and Tekade PR (2011): Profile of organophosphorus poisoning at Maharani Hospital, Jagdalpur, Chhattisgarh: A three years study. J Indian Acad Forensic Med; 33(2): 102-105.
Prabodh SA, Sree PVA, Sarma DVHS et al., (2012): Activity of Serum Cholinesterase in OrganoPhosphorus poisoning cases: A prospective study. JPBMS; 20(20): 1-3.

Shah Harsh D, Makwava P M and Odedara RV (2012): Patients admitted in emergency ward of a tertiary teaching hospital of medical college. JPBMS; 17(17): 1-5.

Singh S, Kumar V, Thakur S et al., (2011): Paraoxonase-1 genetic polymorphisms and susceptibility to DNA damage in workers occupationally exposed to organophosphate pesticides. Toxicol Appl Pharmacol; 252(2): 130-137.

Sirivarasai J, Kaojarern S, Yoovathaworn K et al., (2007): Paraoxonase (PON1) polymorphism and activity as the determinants of sensitivity to organophosphates in human subjects. Chem Biol Interact; 168(3): 184-192.

Smit LA, van-Wendel-de-Joode BN et al., (2003): Neurological symptoms among Sri Lankan farmers occupationally exposed to acetylcholinesterase-inhibiting insecticides. Am J Ind Med; 44(3): 254-264.

Sozmen B, Peker S, Kaya U et al., (2007): Markers of long-term exposure to organophosphorus pesticides in farmers who work in viniculture and tobacco production in Turkey. Toxicol Mech Methods; 17(7): 379-384.

Sozmen EY, Mackness B, Sozmen B et al., (2002): Effect of organophosphate intoxication on human serum paraoxonase. Hum Exp Toxicol; 21(5): 247-252.

Tanrisev M and Toprak O (2004): The relationship of clinical signs with therapy and biochemical parameters in patients with organophosphate intoxication. Eur J Gen Med; 1(2): 32-37.

Thetkathuek A, Keifer M, Fungladda W et al., (2005): Spectrophotometric determination of plasma and red blood cell cholinesterase activity of 53 fruit farm workers pre- and post-exposed chlorpyrifos for one fruit crop. Chem Pharm Bull (Tokyo); 53(4): 422-424.

Zhou ZJ, Zheng J, Wu QE et al., (2007): Carboxylic esterase and its associations with long-term effects of organophosphorus pesticides. BES; 20: $284-290$. 


\title{
الملخص العربي
}

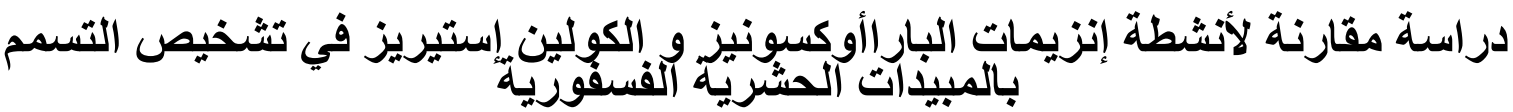

\author{
منى الجوهري 1 و نهلة العشماوي² و رباب الكيلاني1 و أروه أبو الفضل1 و غادة السرنجاوي1
}

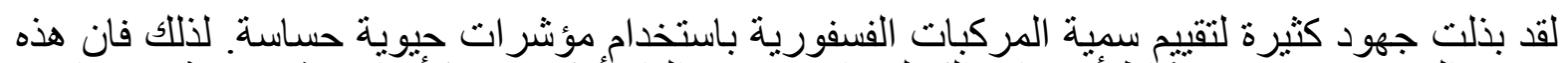

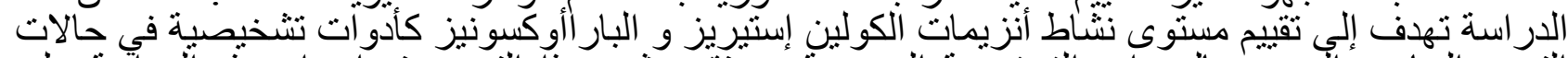

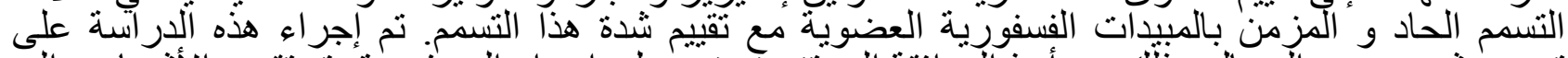

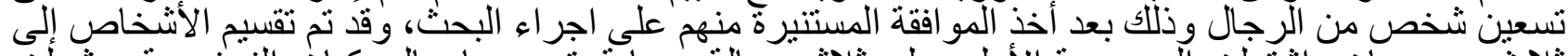

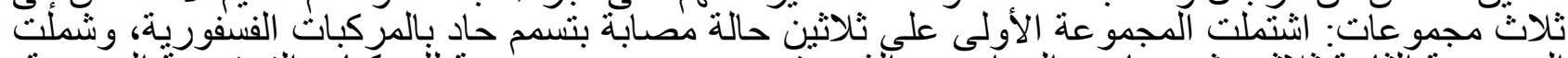

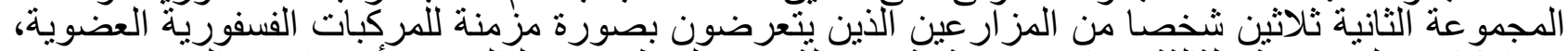

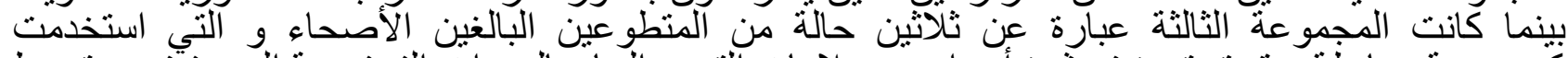

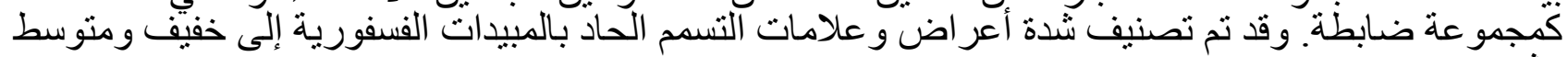

وقد قدرت شدة التعرض للمبيدات فى الأفر اد المعرضين بصورة مزمنة للمركبات الفسفورية العضوية، العاية وشديد.

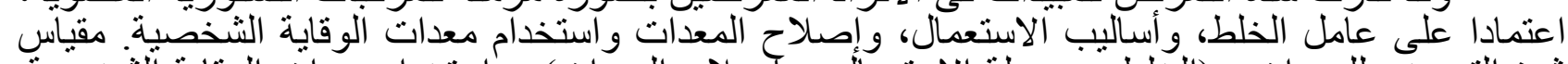

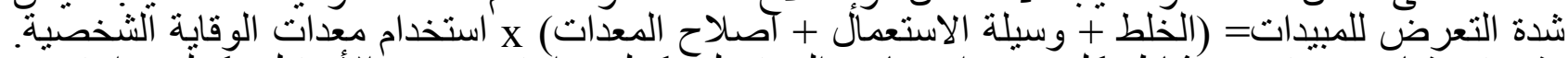

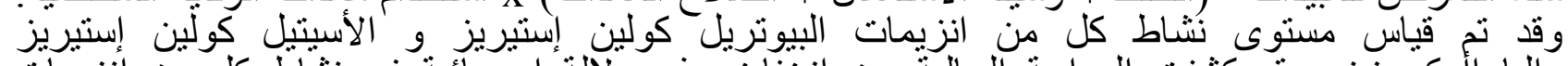

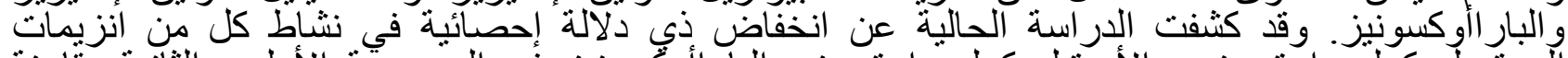

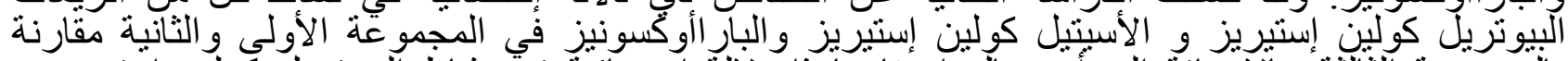

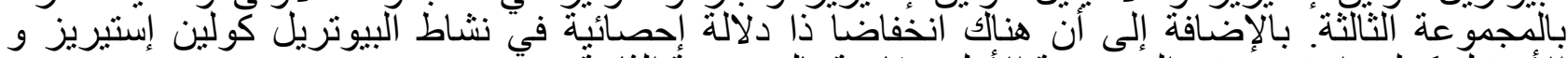

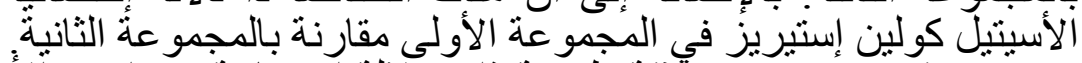

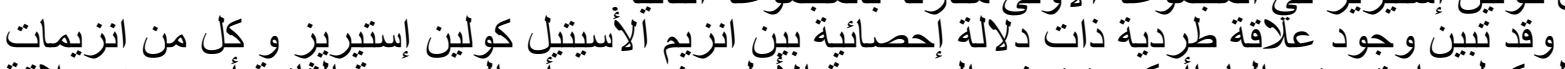

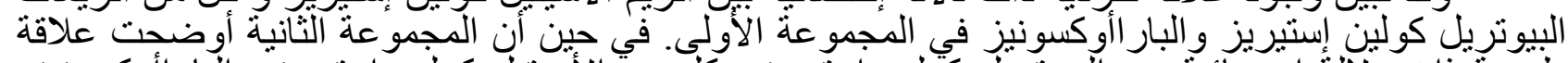

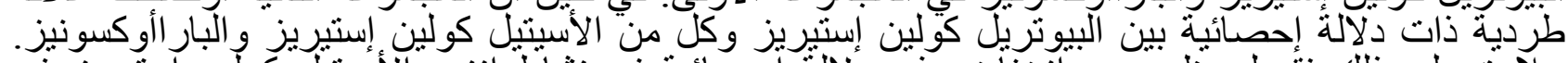

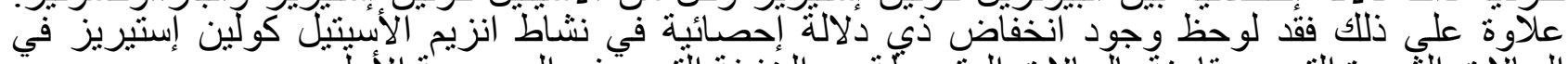

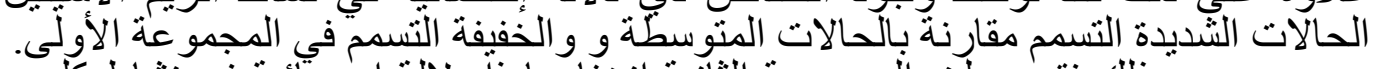

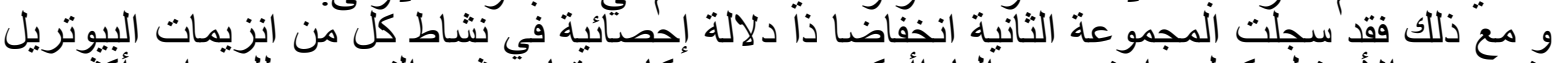

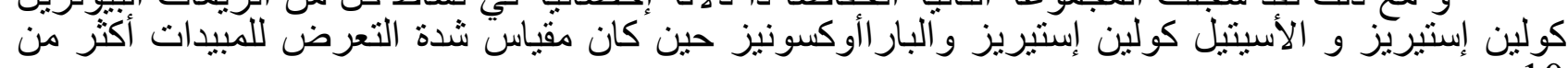

